\title{
Design of T-hangar for Aircraft and Sports Flying Sports Facilities
}

Antonín Svoboda (0000-0002-1749-5703), Jan Štěrba (0000-0002-2676-3562)

Faculty of Mechanical Engineering, J. E. Purkyne University in Usti nad Labem. Pasteurova 3334/7, 40001 Usti nad Labem. Czech Republic. Email: svoban@email.cz,jan.sterba@ujep.cz

This work deals with the construction of a steel hangar with a sheet metal shell for storage sports flying equipment (SPE) or general aviation aircraft. The design of the building was made to ensure an individual approach to each aircraft. The construction was designed with price and safety in mind. An available option is an electronic security system connected to the central security desk via the Internet, mobile phone or other data transmission.

Keywords: T-hangar, ultralight, sport airplane, wind load, snow load, steel construction, weld construction,

\section{Introduction}

After 1989, air sports began to develop very rapidly. With the foundation of the LAA - Light Aircraft Association, flying, especially on ultralight aircraft (sport flying equipment, as stated in the regulation) has become a phenomenon available to almost everyone.

The availability of flying to the general public brought with its secondary problems with fields that serve for take-off and landing of SFE and with the storage of aircraft. With the development of aircraft construction technologies, modern laminate, Kevlar and carbon buildings began to replace the original wooden structures. With the change in technology, the price of SFE also increased. The cost of the wooden structure of an aircraft ranges in tens of thousands of CZK, while a laminate or carbon structure ranges in hundreds of thousands of CZK.

In the 1990s, wooden planes were stored under various amateur shelters, but today the demand for quality and safe storage spaces has increased significantly.

The Faculty of Production Technologies and Management also responded to this increased demand by assigning the work "design of a sheet metal hangar with a steel skeleton".

\section{Current status}

Aircraft clubs, airlines and private owners of SFE and sports aircraft are increasingly raising questions about quality and cheap, yet safe storage of increasingly expensive aircraft. The old buildings of the former and current aircraft clubs do not meet these requirements due to the old uneconomically and impractically designed hangars.

Whether it is a wooden or steel structure, their service life is limited. The method of mass storage of aircraft in one hangar also proves to be a very unfortunate solution. This arrangement involves storing the aircraft by handling it in the hangar and dragging them into each other. These manoeuvres often result in damage and subsequent decommissioning of the aircraft. In more serious cases, repair and inspection costs can reach hundred of thousands CZK.

Another disadvantage is that the required aircraft might have been towed to the further corner of the hangar. Thus, the entire operation of the aircraft is preceded by the handling of all other aircraft out of the hangar and, after taking out the required one, the handling them back to the hangar.

\section{Wind load on the structure}

This load is determined by the standard according to EN 1991-1-4 [20].

The basic dynamic wind pressure $q_{b}$ on the structure is determined from the relation:

$$
q_{b}=\frac{1}{2} \cdot \rho \cdot v_{b}^{2}
$$

Where:

$\mathrm{q}$ - represents bulk density of air $\left(1.25 \mathrm{~kg} / \mathrm{m}^{3}\right), \mathrm{v}_{\mathrm{b}}$ basic wind speed. [20]

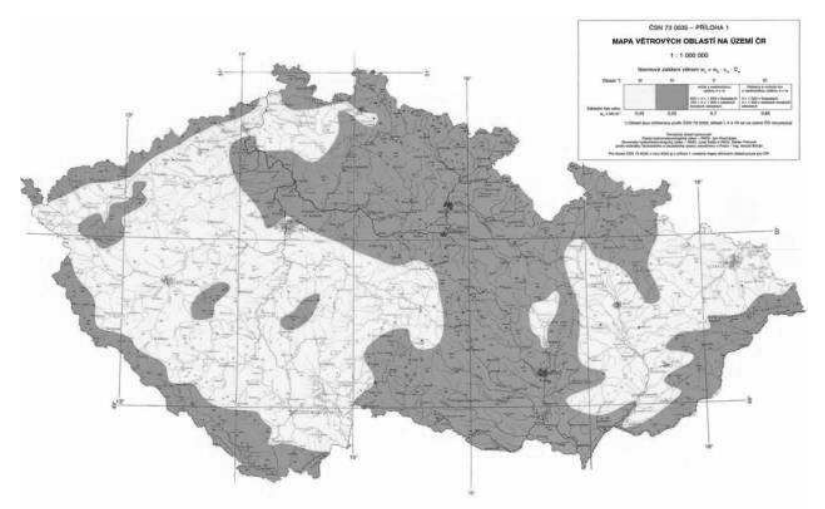

Fig. 1Map of wind areas in the Czech Republic [20]

For a simplified assessment of the effect of wind load, it can be assumed that the basic wind speed $\mathrm{v}_{\mathrm{b}}=$ 
$\mathrm{v}_{\mathrm{b}, 0}$ and that in the Czech Republic the initial wind speed is b, $0=27.5 \mathrm{~m} / \mathrm{s}$ (in most areas it is smaller or the same, in mountain areas is larger). The maximum value of the dynamic wind pressure on the structure is then determined from the relation:

$$
q_{p}=\mathrm{c}_{e}(z) \cdot q_{b}
$$

Where:

ce $(z)$ - represents exposure factor depending on the height above the ground and the terrain category Fig. 2.

The course of the coefficient $c_{e}(z)$ is shown in Fig. 2 for the respective terrain categories.

\section{Snow load on the structure}

The snow load on the structure is determined by the standard according to EN 1991-1-3 [11] and is the main component of the load for which the roof structures are designed.

The characteristic value of snow on the ground is determined depending on the construction site according to the map of snow areas. A new map was published in October 2006 and its use is modified in ČSN EN 1991-1-3 / Amendment Z1 and for the original use of the Czech standard ČSN 730035 / Amendment Z3. [11]

The updated map is based on the values of water weight of snow measured in the period between 1961 and 2006. The characteristic snow load values used in the map are values that can be reached or exceeded once every 50 years. The territory of the Czech Republic is in the map divided into 7 areas with a characteristic value of snow load $0.7-4.0 \mathrm{kPa}$, the 8 th area specifies the area with a characteristic value of snow load higher than $4.0 \mathrm{kPa}$. In this area there is a characteristic snow load $\left(1 \mathrm{kPa}=102 \mathrm{~kg} / \mathrm{m}^{2}\right)$.

Most of the Czech Republic is located in 1. - 4. areas where the characteristic value of snow load is from 0.7 - $2.0 \mathrm{kPa}$. Fig. 2.

When calculating the load-bearing capacity of the roof, the characteristic value is adjusted to the design value depending on the shape and slope of the roof, the height of the building, the exposure of the building in the terrain. The design value during the calculation will also be affected by the material (safety coefficients).

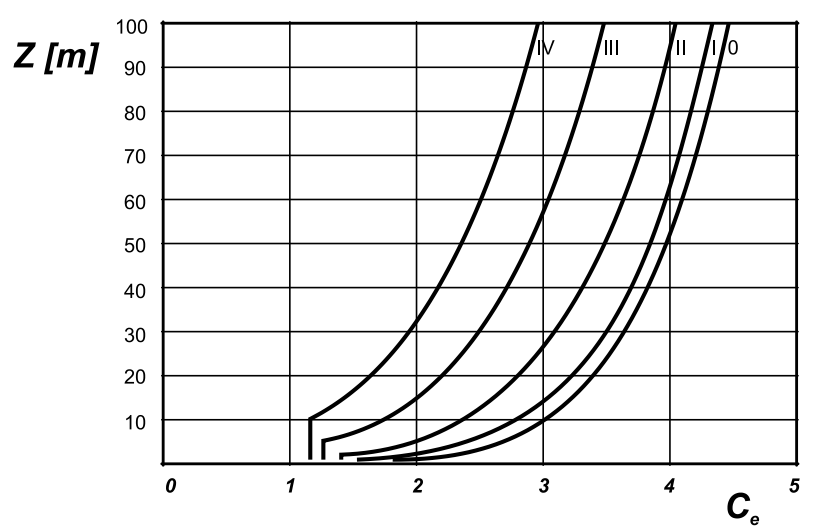

Fig. 2 Terrain height dependent exposure factor [20]

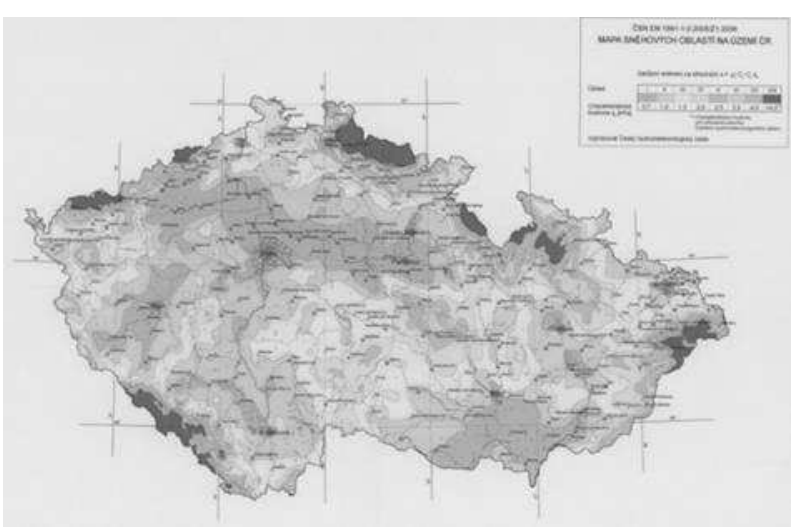

Fig. 3 Map of snow areas in the Crech Republic [21]

Tab. 1 - Map of snow areas in the Czech Republic [21]

\begin{tabular}{|l||l|l|l||l|l|l|l||l|}
\hline Snow area & I & II & III & IV & V & VI & VII & VIII \\
\hline $\mathrm{kN} / \mathrm{m}^{2}$ & 0.7 & 1.0 & 1.5 & 2.0 & 2.5 & 3.0 & 4.0 & $>4.0$ \\
\hline $\mathrm{kg} / \mathrm{m}^{2}$ & 70 & 100 & 150 & 200 & 250 & 300 & 400 & $>480$ \\
\hline
\end{tabular}

Construction with a rectangular ground plan

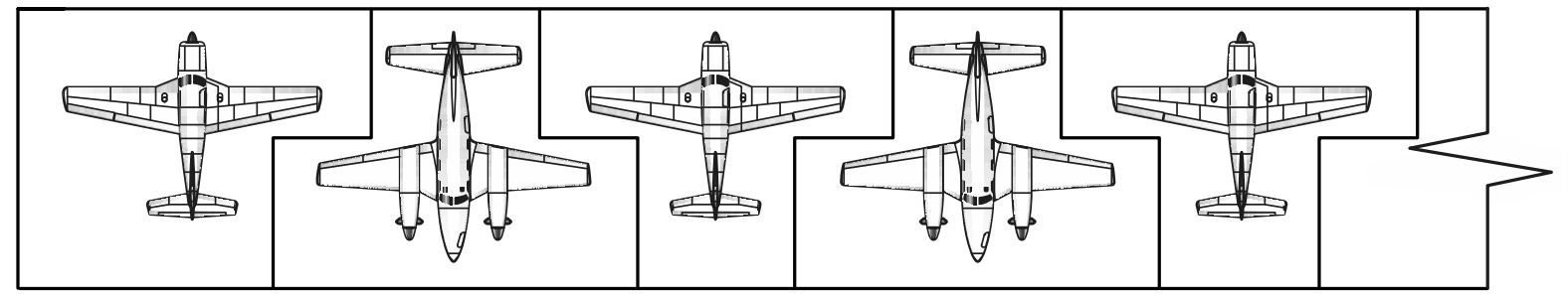

Fig. 4 Structure with a rectangular ground plan

This consideration of the construction of Fig. 6 was chosen as the most efficient, because it met all the assignment requirements. In addition, the construction meets the following requirements:
1) The construction must allow easy handling of the aircraft so that it can be handled by a single person

2) When removing and storing the aircraft in the hangar, other aircraft must not be moved 
3) Minimum built-up area

4) The possibility of expanding storage spaces by extension.

\section{Supporting columns of the building}

Welded parts of "U 400" hot rolled profiles DIN $10025-2,2$ x U 200 consist of a steel bar with a diameter of $20 \mathrm{~mm}$. Below, the diagonal reinforcement is checked by a tensile calculation.

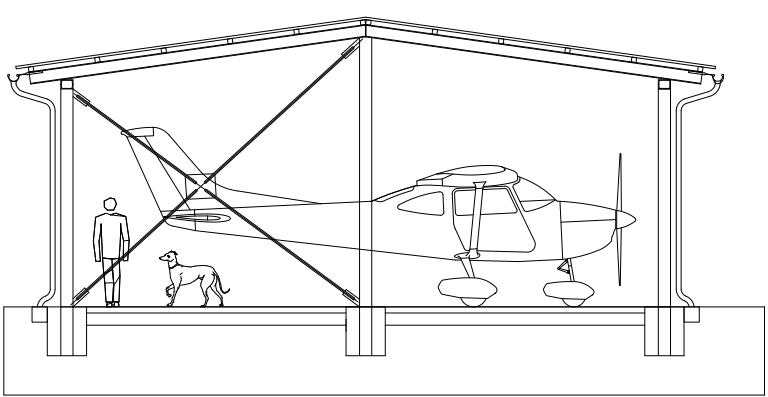

Fig. 5 Diagonal reinforcement of the structure
Force loading the structure from the side:

Wind force - highest load value $=0.85 \mathrm{kN} / \mathrm{m}^{2}$

Calculation of force in the $\mathrm{x}$-axis:

$$
F_{x}=850 \cdot 15=12750 \mathrm{~N}=12,75 \mathrm{kN}
$$

Calculation of force in diagonal beam $\mathrm{Fd}$ (sine theorem):

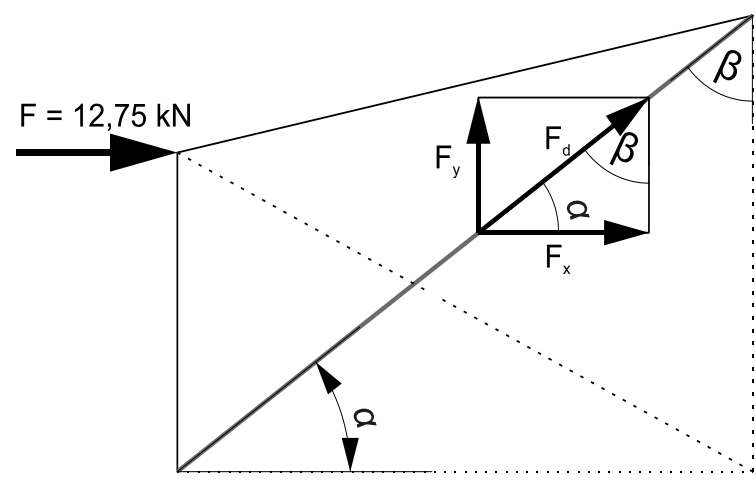

Fig 6 Force ratios of diagonal reinforcement

$\frac{F d}{\sin 90}=\frac{F x}{\sin \beta} \rightarrow F d=\frac{F x \cdot \sin 90}{\sin \beta}=\frac{F_{x} * \sin 90}{\sin 58}=\frac{12750 * 1}{\sin 58}=\frac{12750 * 1}{0,848048}=15034,52 \mathrm{~N}=15 \mathrm{kN}$

Checking the tension of diagonal truss:

$$
\sigma_{t}=\frac{F_{d}}{S} \leq \sigma_{D t}
$$

$$
S=\frac{\pi * d^{2}}{4}=\frac{\pi * 0,02^{2}}{4}=0,0003142 \mathrm{~m}^{2}
$$

$\mathrm{Fd}=15035 \mathrm{~N}$

$$
\sigma_{t}=\frac{15035}{0,0003142}=47851686,82 \mathrm{~Pa}=47,85 \mathrm{MPa}
$$

Number of diagonal reinforcement fields per calculated pressure: 2

$$
\sigma_{t 2}=\frac{47,85}{2}=24 \mathrm{MPa}<370 \mathrm{MPa} \text { diagonal reinforcement COMPLIES }
$$

Checking the columns on the struts

All columns are designed from rolled profiles " $U$ 400", welded with open ends together to form a hollow column [2].
I check the struts according to Euler [2], based on the slenderness of the column $\lambda$.

Euler's formula is valid only if $\lambda \geq \lambda \mathrm{m}$

$\lambda \mathrm{m}$ - ultimate slenderness $=$ material constant

$$
J_{x 2 U}=2 *\left(J_{x}+S * a^{2}\right)=2 *\left(20350+9150 * 110^{2}\right)=221470700 \mathrm{~mm}^{4}
$$

Checking the beam (truss) over the entrance

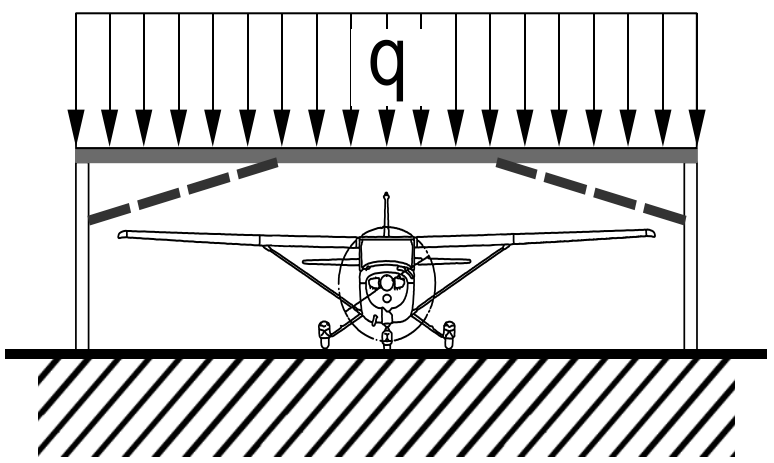

Fig. 7 Entrance truss - the most critical load of the whole building
When calculating in favour of safety, I neglect the corner supports, which I add to the structure only to reduce the deflection of the truss, as well as to increase the lateral stability and better installation conditions of electric rolling shutters.

Tab. 2 Material constants of limiting slenderness

\begin{tabular}{|l|l|}
\hline Carbon steel & $\lambda_{\mathrm{m}}=100$ \\
\hline Alloy steel & $\lambda_{\mathrm{m}}=85$ \\
\hline Grey cast iron & $\lambda_{\mathrm{m}}=80$ \\
\hline Spring steel & $\lambda_{\mathrm{m}}=60$ \\
\hline Wood & $\lambda_{\mathrm{m}}=100$ \\
\hline
\end{tabular}




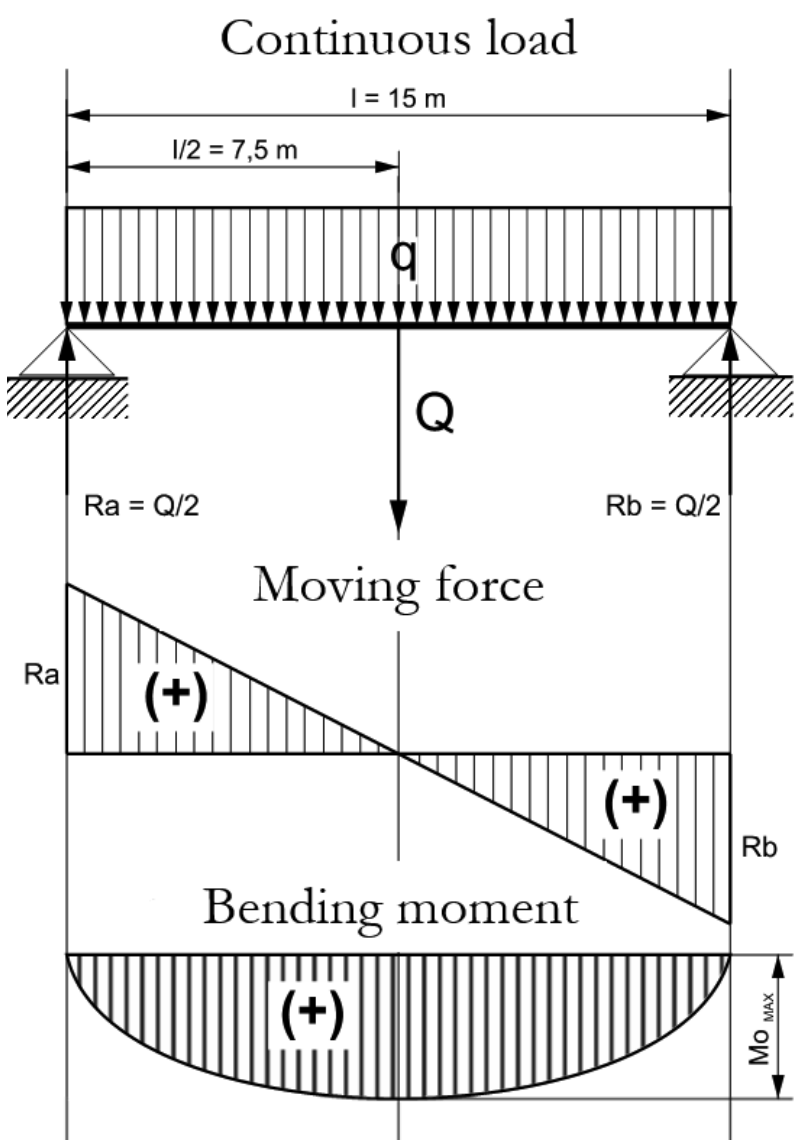

Fig. $\boldsymbol{8}$ The course of the bending moment of the roof beam with the highest load - truss of the entrance to the building $\mathrm{q}=2200 \mathrm{~N} / \mathrm{m}^{2}$ Roof load by all influences

$\mathrm{S}=225 \mathrm{~m}^{2}$ Roof area

$\mathrm{Q}=\mathrm{q} . \mathrm{S}=2200.225$ Force converted from continuous load

$Q=495000$ NLoad on the beam from the entire roof

$\mathrm{Q}_{(1 / 2)}=\mathrm{Q} / 2=495000 / 2=247500$ NForce

acting on half of the roof

$\mathrm{Q}_{\mathrm{n}}=\mathrm{Q}_{(1 / 2)} / 2=247500 / 2=123750 \mathrm{~N}$

The force acting on one beam is based on the force acting on the rectangle of the half roof, i.e. the centre of gravity of the rectangle area, and this is equal to $1 / 2$ the load of half the roof, or $1 / 4$ the entire load of the roof by all influences.

\section{Inspection of roof beams and trusses}

Roof load $=2.2 \mathrm{kN} / \mathrm{m}^{2}$

$$
\sigma_{\max }=\frac{M_{o}}{W_{o}} \leq \sigma_{D o v}
$$

$\boldsymbol{\sigma}_{\boldsymbol{D o v}}$ - for steel S235JR $=230 \mathrm{MPa}$

Where:

$\mathrm{W}_{\mathrm{O}}$ - cross-sectional module in bending, $\mathrm{F}_{\text {truss }}$ force acting on one roof truss, $\mathrm{M}_{\mathrm{O}}$ - bending moment

Number of trusses on half of the roof: 4

$$
\begin{gathered}
Q_{1 / 2}=\frac{Q}{2}=\frac{495000}{2}=247500 \mathrm{~N} \text { - Force acting on half of the roof } \\
F_{v a z}=\frac{Q_{1 / 2}}{4}=\frac{247500}{4}=61875 \mathrm{~N} \text { - Force acting on one truss } \\
M_{o}=F_{v a z} * \frac{l_{v a z}}{2}=61875 * \frac{5}{2}=1546875 \mathrm{Nm} \\
\sigma_{\max }=\frac{1546875}{214000}=7,2 \mathrm{MPa} \\
\sigma_{\max }<\sigma_{D o v} \rightarrow 7,2<230 \text { Roof trusses COMPLY }
\end{gathered}
$$

Calculation of reactions in entrance columns

$$
\begin{gathered}
F_{R A}=F_{R B}=\frac{Q_{n}}{2}=\frac{123750}{2} \\
F_{R A}=F_{R B}=61875 \mathrm{~N}=61,8 \mathrm{kN}
\end{gathered}
$$

Calculation of the maximum bending moment of the beam

$$
M_{\text {omax }}=\frac{q * l^{2}}{4}-\frac{q * l^{2}}{8}=\frac{q * l^{2}}{8}=\frac{Q_{n} * l}{8}=\frac{123750 * 15^{2}}{8}=34804687 \mathrm{Nm}=34804,7 \mathrm{kNm}
$$

\section{Inspection of welds}

Weldability for S235JR material is guaranteed. The assessment of weld load capacity (exact method) is performed according to ČSN EN 1993-1-8 (12/2006): Article 4.5.3.2 (6).

The weakest point of the structure is assessed, i.e. the connection of the diagonal reinforcement with the 
frame of the building.

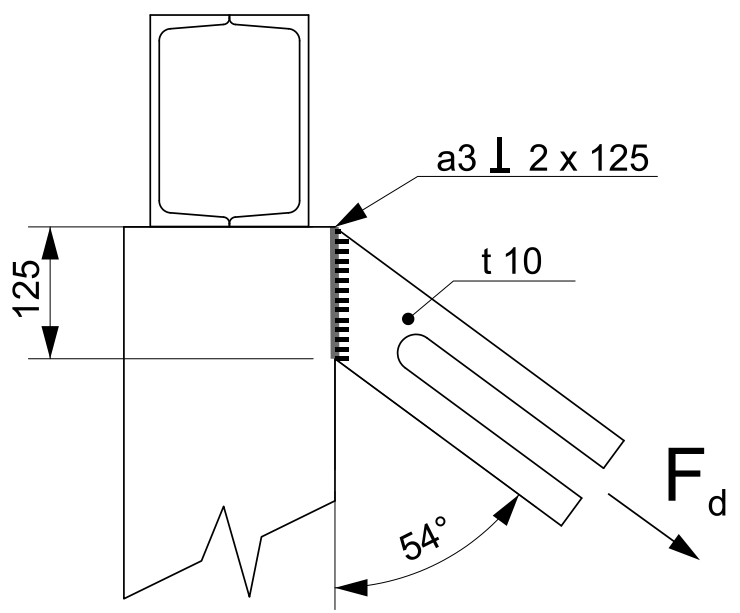

Fig. 9 Weld of the diagonal reinforcement of the frame of the structure - the weld of the structure with the bighest load

$F_{d}=24061 \mathrm{~N}$ Axial force from diagonal reinforcement acting on the weld [8]

$\mathrm{F}_{\mathrm{w}}, \mathrm{R}_{\mathrm{d}}=88100$ Calculated load capacity of 1 weld according to ČSN EN 1993-1-8 (12/2006): Article 4.5.3.2 (6)

Tab. 3 Weld values from steelcalc software

\begin{tabular}{|c|c|c|c|c|c|c|}
\hline $\begin{array}{c}\mathrm{F}_{\mathrm{w}} \\
\mathrm{Rd} \\
{[\mathrm{kN}]}\end{array}$ & $\begin{array}{c}\mathrm{f}_{\mathrm{u}} \\
{[\mathrm{MPa}]}\end{array}$ & $\begin{array}{c}\mathrm{a} \\
{[\mathrm{mm}]}\end{array}$ & $\begin{array}{c}\mathrm{L}_{\mathrm{w}} \\
{[\mathrm{mm}]}\end{array}$ & $\beta_{\mathrm{w}}$ & $\theta$ & $\gamma_{\mathrm{M} 2}$ \\
\hline 88.1 & 360 & 3 & 125 & 0.8 & 54 & 1.25 \\
\hline
\end{tabular}

Number of welds: 2

$F=\frac{F_{w, R d}}{2}=\frac{88100}{2}=44050>24061\left(F_{d}\right)$

The design of the structure is made in accordance with the assignment of this work. The whole design has been checked by calculations in places where the maximum load of the structure occurs. Other elements of the steel skeleton are not addressed in detail, no control calculations of load-bearing capacity were performed because the stress of these parts of the building is negligible and therefore it is not necessary to perform the control by calculation.

The main emphasis of the design was on safety. All designed semi-finished products of the hangar skeleton are therefore chosen so that the control calculation of the load-bearing capacity is far below the maximum stress limit of the elements. The surface treatment of the steel frame is directly related to this. Due to the low cost requirements, no surface treatment is required, but it is recommended. To prolong the service life of the structure, I recommend a high-quality two-component coating, which can extend the service life of the structure by tens of years in terms of protection of the structure against corrosion and other weather conditions.
An option would be the equipment with electrical or mechanical gates, connection to Central Security Desk or satellite, remote control, building status control, etc. Electronic equipment was not the subject of this work, however, I recommend equipping the building with motion sensors connected to alarm and Central Security Desk with SMS transmission to the mobile phone.

\section{References}

[1] In the past, the authors dealt with the calculations of pressure vessels in a number of other scientific works, which helped in solving this work [19-21].

[2] DEJL Z. (2000). Konstrukce stroju a zař̌zeni I. Spoje. Montanex, Ostrava

[3] DOLEŽÍI V., GALIS D. Mechanika II - Výukový manuál

[4] FIALA J., BEBR A., MATOŠKA Z. (1987) Strojnické tabulky 1. Materiály pro strojnickou výrobu. SNTL Praha

[5] FIALA J, BEBR A., MATOŠKA Z., (1988), Strojnické tabulky 2. Základní strojní prvky a součásti. SNTL, Praha, 1988

[6] KALÁB K., Konstrukèní návrh a výpočet svarované ocelové konstrukce. Vysokoškolská prúručka. VŠBTU, Fakulta strojní, Ostrava

[7] VÁVRA P. a kol. (1987), Strojnické tabulky

[8] ZAJÍČEK M., ADÁMEK V., (2000) V Zpèr prǒmých prutù

[9] Projekt OP RLZ Opatření 3.1-0205 - Cvičení stavba a provoz strojů 1 -

[10] Welded joint

[11] Pilot č. 4/1999 - článek str. 12, Levné hangárování sportovních létajících zařízení.

[12] Prospekt firmy ULAS s.r.o., (2009) Allegro 2007 rozměry letounu

[13] http://www.snihnastrese.cz/mapa-snehovychoblasti/

[14] http://www.salvatorstrechy.cz/vetrna-mapa

[15] http://www.normy.biz/normy-na-pozarnibezpecnost-staveb.php

[16] http://lis.rlp.cz/predpisy/predpisy/index.htm

[17] http://www.satjam.cz/

[18] ČERNOHLÁVEK, V., SVOBODA, M., ŠTĚRBA, J., CHALUPA, M., SAPIETA, M.: Analytical and experimental solution of vibrati- 
ons of a system of bound bodies. In: Manufacturing Technology. Vol. 20, No. 6 (2020) pp 699-707. ISSN: 1213-2489. DOI: $10.21062 / \mathrm{mft} .2020 .116$.

[19] KLIMENDA, F., ŠTĚRBA, J., ČERNOHLÁVEK, V., PONIKELSKÝ, J., MAŘAN, P.: Draft of robotic workstation for laser engraving. In: Manufacturing Technology. Vol.
21, No. 3 (2021) pp 357-363. ISSN: 1213-2489. DOI: $10.21062 / \mathrm{mft} .2021 .049$

[20] SAPIETA, M., ŠULKA, P., SVOBODA, M.: Localization of delamination in composite test specimens. In: MATEC Web of Conferences 157, $01015 \quad$ (2018) doi.org/10.1051/matecconf/201815701015 